\title{
Extracellular calcium-sensing receptor: structural and functional features and association with diseases
}

O.M. Hauache

\author{
Correspondence \\ O.M. Hauache \\ Disciplina de Endocrinologia \\ EPM, UNIFESP \\ Rua Pedro de Toledo, $781,12^{\circ}$ andar \\ 04039-032 São Paulo, SP \\ Brasil \\ Fax: +55-11-5084-5231 \\ E-mail: ohauache- \\ endo@ pesquisa.epm.br
}

Research supported by FAPESP.

Received November 30, 2000

Accepted February 16, 2001

\author{
Laboratório de Endocrinologia Molecular, Disciplina de Endocrinologia, \\ Departamento de Medicina, Escola Paulista de Medicina, \\ Universidade Federal de São Paulo, São Paulo, SP, Brasil
}

\section{Abstract}

The recently cloned extracellular calcium-sensing receptor $(\mathrm{CaR})$ is a $\mathrm{G}$ protein-coupled receptor that plays an essential role in the regulation of extracellular calcium homeostasis. This receptor is expressed in all tissues related to this control (parathyroid glands, thyroid Ccells, kidneys, intestine and bones) and also in tissues with apparently no role in the maintenance of extracellular calcium levels, such as brain, skin and pancreas. The $\mathrm{CaR}$ amino acid sequence is compatible with three major domains: a long and hydrophilic aminoterminal extracellular domain, where most of the activating and inactivating mutations described to date are located and where the dimerization process occurs, and the agonist-binding site is located, a hydrophobic transmembrane domain involved in the signal transduction mechanism from the extracellular domain to its respective $G$ protein, and a carboxyterminal intracellular tail, with a well-established role for cell surface $\mathrm{CaR}$ expression and for signal transduction. CaR cloning was immediately followed by the association of genetic human diseases with inactivating and activating $\mathrm{CaR}$ mutations: familial hypocalciuric hypercalcemia and neonatal severe hyperparathyroidism are caused by CaR-inactivating mutations, whereas autosomal dominant hypoparathyroidism is secondary to CaR-activating mutations. Finally, we will comment on the development of drugs that modulate $\mathrm{CaR}$ function by either activating (calcimimetic drugs) or antagonizing it (calcilytic drugs), and on their potential therapeutic implications, such as medical control of specific cases of primary and uremic hyperparathyroidism with calcimimetic drugs and a potential treatment for osteoporosis with a calcilytic drug.

\section{Introduction: an overview of structural and functional features of the extracellular calcium-sensing receptor}

The extracellular calcium-sensing receptor $(\mathrm{CaR})$ was cloned by Brown et al. (1) in 1993 from bovine parathyroid glands. The cloning of this receptor provided valuable information regarding mechanisms related
Key words

- Calcium-sensing receptor

- Familial hypocalciuric hypercalcemia

- Autosomal dominant hypoparathyroidism

- Calcimimetic drugs

- Calcilytic drugs to the control of extracellular calcium homeostasis. Until 1993, hormones such as parathormone (PTH), 1,25-dihydroxyvitamin $\mathrm{D}_{3}$ and calcitonin, interacting with their respective target organs and tissues involved in the regulation of calcium homeostasis, were promptly recognized as major participants in the adequate maintenance of this delicate balance. However, the presumed common mechanism responsible for the sensing of 
minor variations in extracellular calcium concentration could be only successfully identified with the cloning of the CaR (1).

In fact, many papers subsequently demonstrated the expression of the $\mathrm{CaR}$ in all the tissues directly related to the control of calcium homeostasis: human and chicken parathyroid glands; rat, human and rabbit kidney; thyroid rat and human C-cells; human and rat intestine, and also in diverse bone marrow-derived cells $(2,3)$. With this in mind, it is currently accepted that, in addition to serving as an intracellular second messenger, calcium ion also plays a hormone-like role as an extracellular first messenger (4). In this context, there is no doubt that the $\mathrm{CaR}$ plays an essential role in the regulation of extracellular calcium homeostasis, mainly by mediating the inhibitory actions of extracellular calcium on parathyroid hormone secretion by the parathyroid glands and by influencing the rates of renal tubular calcium reabsorption and secretion of calcitonin by thyroidal C-cells. In addition to all these tissues directly involved in the calcium homeostatic system, the CaR seems to be widely distributed, being expressed in tissues with apparently no evident role in the control of

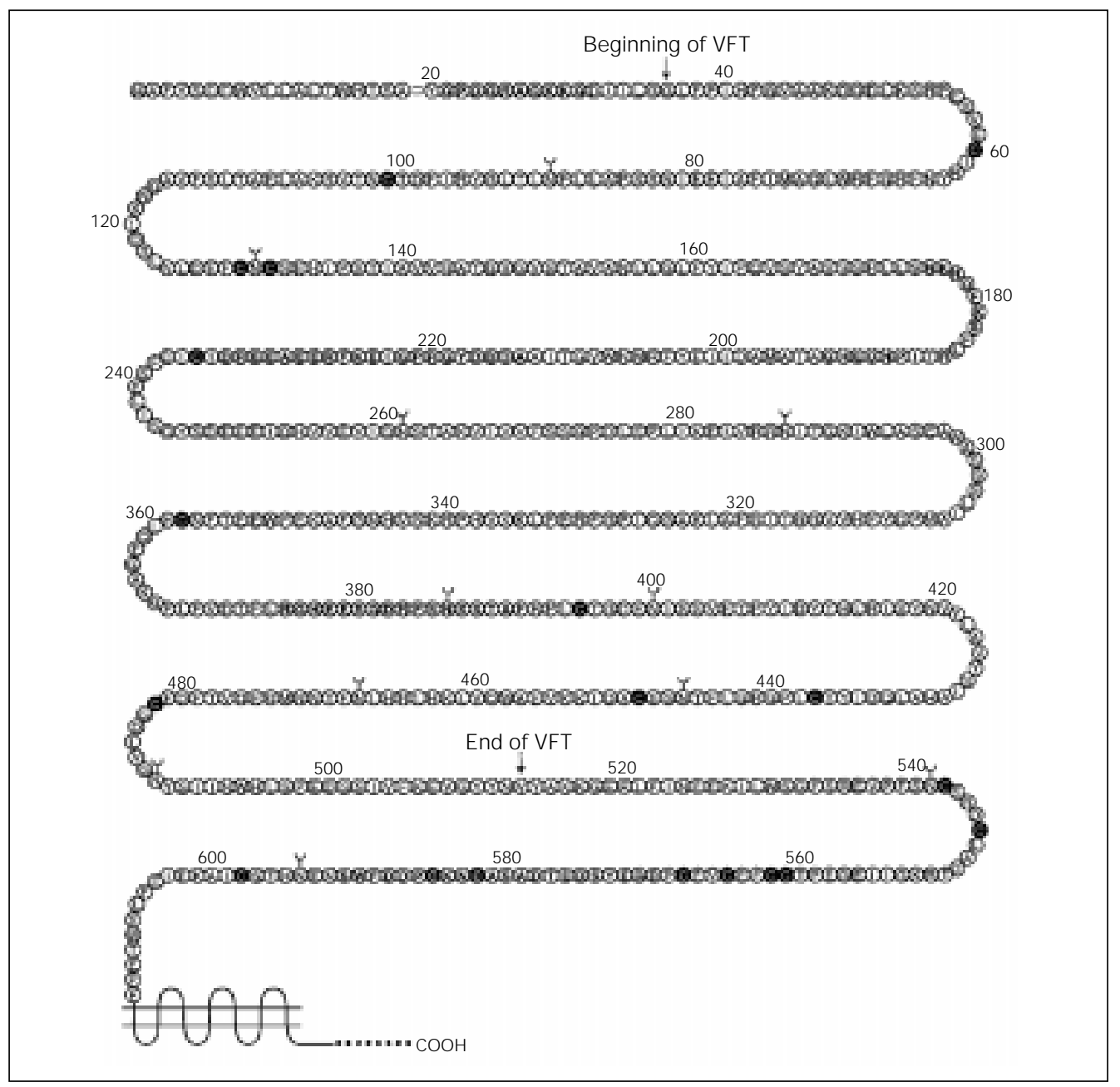

Figure 1. Schematic diagram of the human extracellular calcium-sensing receptor ( $\mathrm{hCaR}$ ) showing the amino acid sequence of the large $\mathrm{hCaR}$ extracellular domain. The location of the $\mathrm{N}$-linked glycosylation sites is shown and all the 19 cysteines are shown inside black circles. The beginning and the end of the putative "venus flytrap" (VFT) domain are indicated. The cysteine-rich domain includes the nine cysteine residues located between C542 and C598. 
extracellular calcium homeostasis, such as breast, keratinocytes, a variety of cells within the central nervous system, pancreas, and lens epithelial cells (2). The specific roles of the $\mathrm{CaR}$ in all these tissues still remain to be elucidated.

Structurally speaking, the human homologue of the $\mathrm{CaR}$ is a $\mathrm{G}$ protein-coupled receptor (GPCR) consisting of 1078 amino acid residues (3). The first 612 amino acids are included in a large extracellular domain (ECD), which is a feature of the subfamily to which the CaR belongs. In addition to the $\mathrm{CaR}$, this subfamily of GPCRs (also called family $\mathrm{C}$ or family 3 ) includes the metabotropic glutamate receptors (5), putative pheromone receptors in the vomeronasal organ (68), putative taste receptors (9) and $\mathrm{GABA}_{\mathrm{B}}$ receptors (10).

Part of this large ECD (from amino acid residue 36 to amino acid residue 513) seems to be structurally related to the bilobed ("venus flytrap") structure of bacterial periplasmic binding proteins (11-14) (Figure 1), and hypothetically the closing of the two lobes after binding of ligands triggers the transmission of signals from the ECD to the receptor's cytoplasmic signaling loops. The $\mathrm{CaR}$ ECD is thought to be the site of $\mathrm{Ca}^{2+}$ binding $(15,16)$ and contains 11 potential Nlinked glycosylation sites $(17,18)$ and a total of 19 cysteines, nine of them being highly conserved and located at the end of the ECD, and constituting the so-called cysteine-rich domain which plays a critical role in signal transduction from the corresponding "venus flytrap" domain to the seven-transmembrane domain (19) (Figure 1). Recent studies have demonstrated that the $\mathrm{CaR}$ is expressed on the cell surface as an intermolecular disulfide-linked dimer $(20,21)$ and cysteine residues which are critical for $\mathrm{CaR}$ dimerization have been identified $(13,22)$. Moreover, heterodimerization of mutant CaRs and intermolecular interactions of the heterodimeric receptor have been shown to be functionally important for receptor-dependent signaling
$(23,24)$ and recent findings have suggested that the CaR has at least two distinct types of motifs mediating dimerization and functional interactions: covalent interactions involving intermolecular disulfide bonds and noncovalent, possibly hydrophobic, interactions (22). Most of the natural activating and inactivating mutations described so far are located in the ECD (Table 1) and a cluster of natural and artificial activating mutations is located between residues Ala116 and Pro136, suggesting that this region is very important

Table 1. Natural activating and inactivating mutations of the human calcium-sensing receptor described to date.

\begin{tabular}{|c|c|c|c|}
\hline Activating mutations & Site & Inactivating mutations & Site \\
\hline K47N & ECD & C7-frameshift & ECD \\
\hline A116T & ECD & Q27R & $\mathrm{ECD}$ \\
\hline N118K & ECD & P39A & ECD \\
\hline L125P & ECD & P40A & $\mathrm{ECD}$ \\
\hline E127A & ECD & S53P & ECD \\
\hline F128L & ECD & P55L & ECD \\
\hline $\mathrm{C} 129 \mathrm{~F}$ & ECD & $\mathrm{R} 62 \mathrm{M}$ & ECD \\
\hline T151M & ECD & $\mathrm{R} 66 \mathrm{C}$ & ECD \\
\hline E191K & ECD & S137P & $\mathrm{ECD}$ \\
\hline P221L & ECD & T138M & ECD \\
\hline E228Q & ECD & G143E & ECD \\
\hline Q245R & ECD & L174R & $\mathrm{ECD}$ \\
\hline Q254R & ECD & N178D & ECD \\
\hline F612S & ECD & R185Q & ECD \\
\hline Q681H & 1st EC loop & D215G & ECD \\
\hline L773R & TM -5 & Y218S & ECD \\
\hline F788C & TM-5 & R220W & ECD \\
\hline F806S & TM-6 & P221S & ECD \\
\hline S820F & TM-6 & $\mathrm{R} 227 \mathrm{~L}(\mathrm{Q})$ & ECD \\
\hline A835T & 3rd EC loop & E297K & $\mathrm{ECD}$ \\
\hline A843E & TM-7 & C395R & ECD \\
\hline S895-V1075 & C-tail & G549R & ECD \\
\hline \multirow[t]{13}{*}{ (in-frame deletion) } & & G552R & ECD \\
\hline & & C582Y & ECD \\
\hline & & S607Stop & ECD \\
\hline & & $\mathrm{R} 648 \mathrm{X}$ & 1st IC loop \\
\hline & & S657Y & $\mathrm{TM}-2$ \\
\hline & & G670R & TM-2 \\
\hline & & $\mathrm{R} 680 \mathrm{C}$ & 1st EC loop \\
\hline & & P747-frameshift & 2nd EC loop \\
\hline & & P748R & 2nd EC loop \\
\hline & & R795W & 3rd IC loop \\
\hline & & V817I & TM-6 \\
\hline & & T876-frameshift & C-tail \\
\hline & & F881L & C-tail \\
\hline
\end{tabular}

ECD, extracellular domain; EC, extracellular; IC, intracellular; TM, transmembrane domain; C-tail, carboxyterminal tail. 
for the maintenance of the inactive conformation of the CaR (25).

$\mathrm{CaR}$ activation by extracellular calcium involves activation of phospholipase $C_{\beta}$ via the $\mathrm{G}_{\mathrm{q}}$ subfamily of $\mathrm{G}$ proteins, with a consequent transient increase of intracellular calcium. Actually, the CaR is thought to couple through its intracellular loops as well as its carboxyterminal intracellular tail (C-tail) to the various $\mathrm{G}$ proteins that mediate its biological actions (including $\mathrm{G}_{\mathrm{q}}$ for activating phospholipase $\mathrm{C}$ and $\mathrm{G}_{\mathrm{i}}$ for inhibiting adenylate cyclase) $(2,4)$. The functional characteristics of the expressed wild-type $\mathrm{CaR}$ are included in the definition of the $\mathrm{EC}_{50}$ for extracellular calcium, which is the effective concentration of extracellular calcium eliciting one half of the maximal intracellular calcium response. This corresponds to a value around $4.1 \mathrm{mM}$ in transiently transfected HEK293 cells (26).

The seven-transmembrane domain, characteristic of the superfamily of GPCRs, is involved in the signal transduction mechanism from the CaR ECD to its respective $G$ protein. In addition (see Table 1), natural activating and inactivating mutations have been identified in the seven-transmembrane domain, including the single constitutive activating mutation (A843E) of the CaR described to date (27). Within the intracellular domains of the human $\mathrm{CaR}$, there are five predicted protein kinase $\mathrm{C}$ phosphorylation sites. The C-tail comprises over 200 amino acid residues and its role for cell surface $\mathrm{CaR}$ expression and for signal transduction has been described. Moreover, it has been demonstrated that the first 20 amino acid residues in the membrane-proximal portion of the $\mathrm{C}$-tail are important for $\mathrm{CaR}$ function $(28,29)$.

\section{Extracellular calcium-sensing receptor: association with diseases}

$\mathrm{CaR}$ cloning was promptly followed by identification of inherited human hypercal- cemic and hypocalcemic disorders, respectively resulting from loss and gain of function mutations in the $\mathrm{CaR}(2,30,31)$. In familial hypocalciuric hypercalcemia $(\mathrm{FHH})$ (32-34) and neonatal severe hyperparathyroidism (NSHPT) (35), loss of function mutations in the CaR lead to generalized resistance to extracellular calcium. The opposite phenotype, hypocalcemia with relative hypercalciuria, is associated with a disorder termed autosomal dominant hypocalcemia (ADH) (36), which has been shown to be caused by gain of function mutations in the CaR leading to hyperresponsiveness to extracellular calcium.

A list of natural activating and inactivating mutations described so far (with their respective locations in the $\mathrm{CaR}$ ) that are associated with these diseases is shown in Table 1. The single exception regarding phenotype is an inactivating mutation (F881L) located in the $\mathrm{C}$-tail which leads to hypercalcemia and hypercalciuria (37).

FHH is inherited as an autosomal-dominant trait with a high penetrance of over $90 \%$ $(33,34)$. The majority of families exhibit linkage of the disease gene to chromosome 3 (band q21-24) known to contain the $\mathrm{CaR}$ gene, but an exception can be illustrated by a family that showed linkage of a phenotypically indistinguishable disorder to the short arm of chromosome 19, band 19p13.3 (38). FHH is a rare disorder of mineral metabolism characterized by lifelong, mild to moderate but usually asymptomatic hypercalcemia. Another feature of this disease is the presence of inappropriately low rates of urinary calcium excretion (a calcium to creatinine clearance ratio of $<0.01)$ and nonsuppressed circulating levels of PTH, regardless of the presence of hypercalcemia $(33,34)$. In short, the diagnosis of FHH can be established by documenting the combination of a low urinary calcium to creatinine clearance ratio, a normal PTH level, and the autosomal-dominant inheritance of mild, asymptomatic hypercalcemia. Consequently and re- 
inforcing the importance of differential diagnosis with primary hyperparathyroidism, surgery (parathyroidectomy) is not indicated and will not improve the hypercalcemia of patients with FHH. Impairment of extracellular calcium sensing by the $\mathrm{CaR}$ in $\mathrm{FHH}$ patients was proven by functional studies in which human embryonic kidney (HEK293) cells were transfected with CaRs bearing FHH mutations. These studies showed an increase in $\mathrm{EC}_{50}$ and many mutants also disclosed a reduction in maximal activity $(26,29)$, supporting previous studies regarding formal testing of calcium-regulated PTH secretion that indicated an increase in setpoint (39).

Due to severe primary hyperparathyroidism with enlargement of all four parathyroid glands, the degree of hypercalcemia in NSHPT is usually more severe than that observed in $\mathrm{FHH}$, and this disorder can be fatal if parathyroidectomy is not carried out within the first weeks of life. Bone demineralization, often accompanied by multiple fractures of long bones and ribs may be present. Some infants with NSHPT represent the homozygous form of FHH (40), or, as seen in one case, a compound heterozygote in which a different inactivating $\mathrm{CaR}$ mutation was inherited from each parent (41). In some cases, NSHPT may be caused by the presence of heterozygous inactivating mutations of the CaR, either in a familial setting or as a de novo mutation in the offspring of normal parents, and possibly in these cases the mutant CaR can exert a "dominant" negative action, impairing the function of the normal receptor (42). Recently, mice heterozygous or homozygous for targeted inactivation of the $\mathrm{CaR}$ gene have been developed. These mice shared biochemical features of $\mathrm{FHH}$ and NSHPT, supporting the physiological importance of $\mathrm{CaR}$ in mineral ion metabolism (43).

A heterozygous germline activating missense mutation of the human $\mathrm{CaR}$ inhibits PTH secretion and reduces renal calcium reabsorption at an inappropriately low serum calcium concentration, leading to hypocalcemia, relative hypercalciuria and an inappropriately low serum PTH that characterizes subjects with ADH or sporadic hypocalcemia $(27,44)$. Pearce et al. (36) studied six families with $\mathrm{ADH}$ and verified that, in addition to having asymptomatic hypocalcemia with detectable PTH levels, affected family members also had hypomagnesemia and hyperphosphatemia. Differently from what occurs in hypoparathyroidism, there is resetting of the calcium homeostatic system downward, maintaining the extracellular calcium at subnormal concentrations. In addition, a reason for classifying these families as ADH instead of familial isolated hypoparathyroidism is their response to vitamin $\mathrm{D}$ treatment. When an attempt was made to normalize their serum calcium levels with calcitriol, marked hypercalciuria with resultant nephrocalcinosis was observed in some cases. Some of them apparently also developed nephrogenic diabetes insipidus. Therefore, it seems that the calcium homeostatic system of these individuals is adjusted to a lower than normal serum calcium concentration, and attempts to make them normocalcemic result in "hypercalcemic" manifestations, such as hypercalciuria and nephrogenic diabetes insipidus (35). CaR mutations in $\mathrm{ADH}(36,44)$, with one single exception (27), cause increased sensitivity to extracellular calcium rather than constitutive activation. Expression of CaRs harboring activating mutations in HEK293 cells revealed reductions in $\mathrm{EC}_{50}$ of the mutant receptors $(26,44,45)$

\section{Extracellular calcium-sensing receptor: therapeutic implications}

The CaR responds to many polycationic ligands, including divalent and trivalent cations (i.e., $\mathrm{Ca}^{2+}, \mathrm{Mg}^{2+}, \mathrm{Gd}^{3+}$ ) and polyamines (neomycin and spermine) when expressed in either Xenopus laevis oocytes or HEK293 
cells $(1,26,46)$. It has been recently shown that the $\mathrm{CaR}$ can be also activated by amino acids, especially aromatic amino acids, and this finding may help to explain some actions of dietary proteins on calcium metabolism (47).

Since the CaR represents a potential therapeutic target for disorders in which the receptor is inappropriately overactive or underactive (48), some compounds have been developed with the aim of either activating (calcimimetics) (49) or inactivating (calcilytics) (50) the $\mathrm{CaR}$.

A so-called calcimimetic agent NPS R568 (49) has been shown to actually increase $\mathrm{CaR}$ sensitivity to $\mathrm{Ca}^{2+}$ and this action has been demonstrated to successfully inhibit PTH secretion in vitro and in subjects with primary hyperparathyroidism (51), including a patient with parathyroid carcinoma (52), and also in rats and patients with uremic hyperparathyroidism $(53,54)$. In primary hyperparathyroidism, oral NPS R-568 produces fast (within minutes) and substantial $(>50 \%)$ decreases in circulating PTH, followed hours later by reductions in serum calcium concentration at higher doses. In this context, this calcimimetic resets the elevated set-point of pathological parathyroid glands toward normal (2). As expected, a short-term use of this calcimimetic was also associated with an increase in urinary calcium excretion in hypercalcemic patients with primary hyperparathyroidism (51), sug- gesting that a $\mathrm{CaR}$ antagonist could be very useful for the treatment of calcium-containing renal stones. The site of action of R-568 appears to be within and specific for the seven-transmembrane domain of the $\mathrm{CaR}$ (45).

Based on previous studies $(55,56)$ showing that PTH is a potential anabolic agent for the bone and consequently a promising drug for the management of osteoporosis, Gowen et al. (50) recently studied the effects of antagonizing the parathyroid calcium receptor with the use of a so-called calcilytic drug (termed NPS 2143) in osteopenic ovariectomized rats. These authors observed an increase in endogenous PTH secretion leading to a significant increase in bone turnover. These preliminary results suggest that this or future similar drugs may be potential candidates for the treatment of osteoporosis. Future understanding of the functions of the expressed $\mathrm{CaR}$ in tissues with apparently no kind of role in the maintenance of extracellular calcium levels may suggest additional therapeutic roles for $\mathrm{CaR}$ agonists or antagonists (2).

\section{Acknowledgments}

O.M. Hauache wishes to thank A.M. Spiegel for the valuable opportunity of working under his supervision at the Metabolic Diseases Branch - NIDDK, National Institutes of Health (Bethesda, MD, USA).

\section{References}

1. Brown EM, Gamba G, Riccardi D, Lombardi $M$, Butters $R$, Kifor $O$, Sun $A$, Hediger MA, Lytton J \& Hebert SC (1993). Cloning and characterization of an extracellular $\mathrm{Ca}^{2+}$ sensing receptor from bovine parathyroid. Nature, 366: 575-580.

2. Brown EM (1999). Physiology and pathophysiology of the extracellular calciumsensing receptor. American J ournal of Medicine,106: 238-253.

3. Bai M (1999). Structure and function of the extracellular calcium-sensing receptor
(Review). International J ournal of M olecular Medicine, 4: 115-125.

4. Brown EM (1991). Extracellular $\mathrm{Ca}^{2+}$ sensing, regulation of parathyroid cell function, and role of $\mathrm{Ca}^{2+}$ and other ions as extracellular (first) messengers. Physiological Reviews, 71: 371-411.

5. Nakanishi S (1992). Molecular diversity of glutamate receptors and implications for brain function. Science, 258: 597-603.

6. Matsunami H \& Buck LB (1997). A multigene family encoding a diverse array of putative pheromone receptors in mammals. Cell, 90: 775-784.

7. Ryba NJ \& Tirindelli R (1997). A new multigene family of putative pheromone receptors. Neuron, 19: 371-379.

8. Herrada G \& Dulac C (1997). A novel family of putative pheromone receptors in mammals with a topographically organized and sexually dimorphic distribution. Cell, 90: 763-773.

9. Hoon MA, Adler E, Lindemeier J Battey J F, Ryba NJ P \& Zuker CS (1999). Putative 
mammalian taste receptors: a class of taste-specific GPCRs with distinct topographic selectivity. Cell, 96: 541-551.

10. Kaupmann K, Huggel K, Heid J , Flor PJ , Bischoff S, Mickel SJ , McMaster G, Angst C, Bittiger H, Froestl W \& Bettler B (1997). Expression cloning of GABA(B) receptors uncovers similarity to metabotropic glutamate receptors. Nature, 386: 239-246.

11. O'Hara PJ , Sheppard PO, Thogersen H, Venezia D, Haldeman BA, McGrane V, Houamed KM, Thomsen C, Gilbert TL \& Mulvihill ER (1993). The ligand-binding domain in metabotropic glutamate receptors is related to bacterial periplasmic binding proteins. Neuron, 11: 41-52.

12. Goldsmith PK, Fan GF, Ray K, Shiloach J , MCPhie $P$, Rogers $K V$ \& Spiegel AM (1999). Expression, purification and biochemical characterization of the aminoterminal extracellular domain of the human calcium receptor. J ournal of Biological Chemistry, 274: 11303-11309.

13. Ray K, Hauschild BC, Steinbach PJ , Goldsmith PK, Hauache $O \&$ Spiegel AM (1999). Identification of the cysteine residues in the amino-terminal extracellular domain of the human $\mathrm{Ca}^{2}+$ receptor critical for dimerization. Implications for function of monomeric $\mathrm{Ca}^{2+}$ receptor. J ournal of Biological Chemistry, 274: 2764227650.

14. Galvez T, Parmentier ML, J oly $C$, Malitschek B, Kaupmann K, Kuhn R, Bittiger $\mathrm{H}$, Froestl W, Bettler B \& Pin J P (1999). Mutagenesis and modeling of the GABAB receptor extracellular domain support a venus flytrap mechanism for ligand binding. J ournal of Biological Chemistry, 274: 13362-13369.

15. Hammerland LG, Krapcho KJ , Garrett J E, Alasti N, Hung BC, Simin RT, Levinthal C, Nemeth EF \& Fuller FH (1999). Domains determining ligand specificity for $\mathrm{Ca}^{2+}$ receptors. Molecular Pharmacology, 55: 642-648.

16. Bräuner-Osborne $H$, J ensen $A A$, Sheppard PO, O'Hara P \& Krogsgaard-Larsen P (1999). The agonist-binding domain of the calcium-sensing receptor is located at the amino-terminal domain. J ournal of Biological Chemistry, 274: 18382-18386.

17. Fan GF, Goldsmith PK, Collins R, Dunn CK, Krapcho KJ , Rogers KV \& Spiegel AM (1997). N-linked glycosylation of the human $\mathrm{Ca}^{2+}$ receptor is essential for its expression at the cell surface. Endocrinology, 138: 1916-1922.

18. Ray K, Clapp P, Goldsmith PK \& Spiegel AM (1998). Identification of the sites of $\mathrm{N}$ linked glycosylation on the human calcium receptor and assessment of their role in cell surface expression and signal transduction. J ournal of Biological Chemistry, 273: 34558-34567.

19. Hu J, Hauache $\mathrm{O} \&$ Spiegel AM (2000). Human $\mathrm{Ca}^{2+}$ receptor cysteine-rich domain. Analysis of function of mutant and chimeric receptors. J ournal of Biological Chemistry, 275: 16382-16389.

20. Bai M, Trivedi S \& Brown EM (1998). Dimerization of the extracellular calciumsensing receptor ( $\mathrm{CaR})$ on the cell surface of CaR-transfected HEK293 cells. J ournal of Biological Chemistry, 273: 2360523610.

21. Fan GF, Ray K, Zhao XM, Goldsmith PK \& Spiegel AM (1998). Mutational analysis of the cysteines in the extracellular domain of the human $\mathrm{Ca}^{2+}$ receptor: effects on cell surface expression, dimerization and signal transduction. FEBS Letters, 436: 353-356.

22. Zhang Z, Sun S, Quinn SJ, Brown EM \& Bai M (2001). The extracellular calciumsensing receptor dimerizes through multiple types of intermolecular interactions. J ournal of Biological Chemistry, 276: 5316-5322.

23. Bai M, Trivedi S, Kifor O, Quinn SJ \& Brown EM (1999). Intermolecular interactions between dimeric calcium-sensing receptor monomers are important for its normal function. Proceedings of the National Academy of Sciences, USA, 96: 2834-2839.

24. Hauache OM, Hu J, Ray K \& Spiegel AM (2000). Functional interactions between the extracellular domain and the seventransmembrane domain in $\mathrm{Ca}^{2+}$ receptor activation. Endocrine, 13: 63-70.

25. J ensen AA, Spalding TA, Burstein ES, Sheppard PO, O'Hara PJ, Brann MR, Krogsgaard-Larsen $\mathrm{P} \&$ B Bäuner-Osborne $H$ (2000). Functional importance of the Ala116-Pro136 region in the calcium-sensing receptor. Constitutive activity and inverse agonism in a family C G-proteincoupled receptor. J ournal of Biological Chemistry, 275: 29547-29555.

26. Bai M, Quinn S, Trivedi S, Kifor O, Pearce SHS, Pollak MR, Krapcho K, Hebert SC \& Brown EM (1996). Expression and characterization of inactivating and activating mutations in the human $\mathrm{Ca}_{0}{ }^{2+}$-sensing receptor. J ournal of Biological Chemistry, 271: 19537-19545.

27. Zhao XM, Hauache $O$, Goldsmith PK, Collins R \& Spiegel AM (1999). A missense mutation in the seventh transmembrane domain constitutively activates the human $\mathrm{Ca}^{2+}$ receptor. FEBS Letters, 448:
180-184.

28. Ray K, Fan GF, Goldsmith PK \& Spiegel AM (1997). The carboxyl terminus of the human calcium receptor. Requirements for cell-surface expression and signal transduction. J ournal of Biological Chemistry, 272: 31355-31361.

29. Bai M, J anicic N, Trivedi S, Quinn SJ , Cole DEC, Brown EM \& Hendy GN (1997). Markedly reduced activity of mutant calcium-sensing receptor with an inserted Alu element from a kindred with familial hypocalciuric hypercalcemia and neonatal severe hyperparathyroidism. J ournal of Clinical Investigation, 99: 1917-1925.

30. Pollak M, Brown EM, Chou YH, Hebert SC, Marx SJ , Steinmann B, Levi T, Seidman CE \& Seidman J G (1993). Mutations in the human $\mathrm{Ca}^{2+}$-sensing receptor gene cause familial hypocalciuric hypercalcemia and neonatal severe hyperparathyroidism. Cell, 75: 1297-1303.

31. Pollak M, Brown E, Estep H, McLaine $P$, Kifor O, Park J , Hebert S, Seidman C \& Seidman J G (1994). Autosomal dominant hypocalcaemia caused by $\mathrm{Ca}^{2+}$-sensing receptor gene mutation. Nature Genetics, 8: 303-307.

32. Foley $\mathrm{J} \mathrm{r}$ T, Harrison $\mathrm{H}$, Arnaud $\mathrm{C} \&$ Harrison $H$ (1972). Familial benign hypercalcemia. J ournal of Pediatrics, 81: 1060-1067.

33. Marx SJ, Attie MF, Levine MA, Spiegel AM, Downs J r RW \& Lasker RD (1981). The hypocalciuric or benign variant of familial hypercalcemia: clinical and biochemical features in fifteen kindreds. Medicine, 60: 397-412.

34. Law J r WM \& Heath III H (1985). Familial benign hypercalcemia (hypocalciuric hypercalcemia). Clinical and pathogenetic studies in 21 families. Annals of Internal Medicine, 105: 511-519.

35. Chattopadhyay N, Mithal A \& Brown EM (1996). The calcium-sensing receptor: a window into the physiology and pathophysiology of mineral ion metabolism. Endocrine Reviews, 17: 289-307.

36. Pearce $\mathrm{SH}$, Williamson $\mathrm{C}$, Kifor $\mathrm{O}$, Bai M, Coulthard MG, Davies M, Lewis-Barned $\mathrm{N}$, McCredie D, Powell H, Kendall-Taylor P, Brown EM \& Thakker RV (1996). A familial syndrome of hypocalcemia with hypercalciuria due to mutations in the calcium-sensing receptor. New England J ournal of Medicine, 335: 1115-1122.

37. Carling $T$, Szabo $E$, Bai $M$, Ridefelt $P$, Westin G, Gustavsson P, Trivedi S, Hellman P, Brown EM, Dahl N \& Rastad J (2000). Familial hypercalcemia and hypercalciuria caused by a novel mutation in the cytoplasmic tail of the calcium recep- 
tor. J ournal of Clinical Endocrinology and Metabolism, 85: 2042-2047.

38. Heath $\mathrm{H}, \mathrm{J}$ ackson $\mathrm{C}$, Otterud B \& Leppert M (1993). Genetic linkage analysis of familial benign (hypocalciuric) hypercalcemia: evidence for locus heterogeneity. American J ournal of Human Genetics, 53: 193-200.

39. Khosla S, Ebeling PR, Firek AF, Burritt MM, Kao PC \& Heath 3rd H (1993). Calcium infusion suggests a "set-point" abnormality of parathyroid gland function in familial benign hypercalcemia and more complex disturbances in primary hyperparathyroidism. J ournal of Clinical Endocrinology and Metabolism, 76: 715-720.

40. Pollak MR, Chou YH, Marx SJ , Steinmann B, Cole DE, Brandi ML, Papapoulos SE, Menko FH, Hendy GN, Brown EM, Seidman CE \& Seidman J G (1994). Familial hypocalciuric hypercalcemia and neonatal severe hyperparathyroidism. Effects of mutant gene dosage on phenotype. J ournal of Clinical Investigation, 93: 11081112.

41. Kobayashi M, Tanaka H, Tsuzuki K, Tsuyuki M, Igaki H, Ichinose $\mathrm{Y}$, Aya K, Nishioka N $\&$ Seino $Y$ (1997). Two novel missense mutations in calcium-sensing receptor gene associated with neonatal severe hyperparathyroidism. J ournal of Clinical Endocrinology and Metabolism, 82: 27162719.

42. Bai M, Pearce SH, Kifor O, Trivedi S, Stauffer UG, Thakker RV, Brown EM \& Steinmann B (1997). In vivo and in vitro characterization of neonatal hyperparathyroidism resulting from a de novo, heterozygous mutation in the $\mathrm{Ca}^{2+}$-sensing receptor gene: normal maternal calcium homeostasis as a cause of secondary hyperparathyroidism in familial benign hypocalciuric hypercalcemia. J ournal of Clinical Investigation, 99: 88-96.

43. Ho C, Conner DA, Pollak MR, Ladd DJ, Kifor O, Warren HB, Brown EM, Seidman
J G \& Seidman CE (1995). A mouse model of human familial hypocalciuric hypercalcemia and neonatal severe hyperparathyroidism. Nature Genetics, 11: 389-394.

44. De Luca F, Ray K, Mancilla EE, Fan GF, Winer KK, Gore P, Spiegel AM \& Baron J (1997). Sporadic hypoparathyroidism caused by de novo gain-of-function mutations of the $\mathrm{Ca}^{2+}$-sensing receptor. J ournal of Clinical Endocrinology and Metabolism, 82: 2710-2715.

45. Hauache OM, Hu J, Ray K, Xie R, J acobson KA \& Spiegel AM (2000). Effects of a calcimimetic compound and naturally activating mutations on the human $\mathrm{Ca}^{2+}$ receptor and on $\mathrm{Ca}^{2+}$ receptor/metabotropic glutamate chimeric receptors. Endocrinology, 141: 4156-4163.

46. Garrett J E, Capuano IV, Hammerland LG, Hung BCP, Brown EM, Hebert SC, Nemeth EF \& Fuller F (1995). Molecular cloning and functional expression of human parathyroid calcium receptor CDNAs. J ournal of Biological Chemistry, 270: 12919-12925.

47. Conigrave $A D$, Quinn SJ \& Brown EM (2000). L-amino acid sensing by the extracellular $\mathrm{Ca}^{2+}$ sensing receptor. Proceedings of the National Academy of Sciences, USA, 97: 4814-4819.

48. Nemeth EF, Steffey ME \& Fox J (1996). The parathyroid calcium receptor: a novel therapeutic target for treating hyperparathyroidism. Pediatric Nephrology, 10: 275279.

49. Nemeth EF, Steffey ME, Hammerland LG, Hung BCP, Van Wagenen BC, DelMar EG $\&$ Balandrin MF (1998). Calcimimetics with potent and selective activity on the parathyroid calcium receptor. Proceedings of the National Academy of Sciences, USA, 95: 4040-4045.

50. Gowen M, Stroup GB, Dodds RA, J ames IE, Votta BJ, Smith BR, Bhatnagar PK, Lago AM, Callahan J F, DelMar EG, Miller MA, Nemeth EF \& Fox J (2000). Antago- nizing the parathyroid calcium receptor stimulates parathyroid hormone secretion and bone formation in osteopenic rats. J ournal of Clinical Investigation, 105: 1595-1604.

51. Silverberg SJ , Bone 3rd HG, Marriott TB, Locker FG, Thys-J acobs S, Dziem G, Kaatz S, Sanguinetti EL \& Bilezikian J P (1997). Short-term inhibition of parathyroid hormone secretion by a calcium-receptor agonist in patients with primary hyperparathyroidism. New England J oumal of Medicine, 337: 1506-1510.

52. Collins MT, Skarulis MC, Bilezikian JP, Silverberg SJ, Spiegel AM \& Marx SJ (1998). Treatment of hypercalcemia secondary to parathyroid carcinoma with a novel calcimimetic agent. J oumal of Clinical Endocrinology and Metabolism, 83: 1083-1088.

53. Chin J, Miller SC, Wada M, Nagano N, Nemeth EF \& Fox J (2000). Activation of the calcium receptor by a calcimimetic compound halts the progression of secondary hyperparathyroidism in uremic rats. J ournal of the American Society of Nephrology, 11: 903-911.

54. Goodman WG, Frazao J M, Goodkin DA Turner SA, Liu W \& Coburn J W (2000). A calcimimetic agent lowers plasma parathyroid hormone levels in patients with secondary hyperparathyroidism. Kidney International, 58: 436-445.

55. Cosman F \& Lindsay R (1998). Is parathyroid hormone a therapeutic option for osteoporosis? A review of the clinical evidence. Calcified Tissue International, 62: 475-480.

56. Finkelstein JS, Klibanski A, Arnold AL, Toth TL, Hornstein MD \& Neer RM (1998). Prevention of estrogen deficiency-related bone loss with human parathyroid hormone-(1-34): a randomized controlled trial. J ournal of the American Medical Association, 280: 1067-1073. 